\title{
Stoic Democrats? Anti-politics, elite cynicism and the policy process
}

\author{
John Boswell and Jack Corbett
}

\begin{abstract}
Disenchantment with politics appears to be proliferating throughout contemporary liberal democracies, as outlined in the growing literature on anti-politics. Overwhelmingly, this literature has focused on the disaffection citizens express towards the policy process. Here, using policymaking on the issue of obesity in Australia and Britain as a case study, we show that disenchantment is not limited to citizen outsiders; the elite policy actors at the core of the process are cynical, too. Indeed, we unveil an elite cast of 'stoic democrats' who see little reward for their continual efforts. We also point to the limits of stoicism highlighted by this 'extreme’ case, as some elites begin to challenge the legitimacy of formal policy processes, subvert their norms, or ignore them altogether, all in search of more direct impact. We conclude that the literature on anti-politics would benefit from paying greater attention to the potential challenge elite cynicism presents to democratic governance.
\end{abstract}

\section{KEY WORDS}

Anti-politics; network governance; wicked problems; obesity; deliberation

\section{INTRODUCTION}

At the start of the first episode of The Hollowmen, a political satire set in the fictional

Central Policy Unit in Canberra, the Unit's leader enters the office to urgent chatter. 
Discussion centres on the Prime Minister's appearance on a talk radio show, during which he had expressed earnest concern about skyrocketing rates of obesity and promised the electorate urgent action on this pressing public health matter. The episode charts the Unit's efforts to follow through on this promise. Their ambitions for major policy innovation quickly founder as the complex science and politics of the issue dawn on them. Their efforts instead culminate in the Prime Minister donning a carrot costume as part of an obesity awareness campaign, against the backdrop of a comprehensive, timeconsuming and, most importantly, conflict neutralising process of stakeholder engagement.

In real life, around the time the episode screened on Australian television, new Prime Minister Kevin Rudd and Minister for Health and Ageing, Nicola Roxon, expressed earnest concern about skyrocketing rates of obesity and promised the electorate urgent action on this pressing public health matter. Their stated ambitions for major policy reform, however, foundered in the face of the complex science and politics of the issue. Their efforts instead culminated in a public awareness campaign fronted by an animated blue balloon man, against the backdrop of multiple comprehensive, time-consuming and, by common perception, conflict neutralising processes of stakeholder engagement.

This is not just a case of life imitating art. The key advisor to the show's writer was a prominent public health advocate, and its cynical prediction a product of her own fatalism. She reflected: 
I said to someone that we finally reached the end of that episode with the blue man ... Thank God that's over. The relief. I was just waiting for it to finish. My life has just played out. [The Hollowmen] did it in 40 minutes. It took me 4 years. (Interview with Australian public health advocate, June 2011)

This type of cynical disenchantment with the way we are governed will not be unfamiliar to students of policy and politics. Indeed, there is a burgeoning literature that highlights an apparent rise in negative beliefs about democratic government (see Norris 2011; Stoker 2006; Hay 2007; Hay and Stoker 2009; Flinders 2012; Fawcett and Marsh 2014; Wood and Flinders 2014). The prevailing diagnosis of this problem is that it is the symptom of a growing 'gap’ or 'deficit' created by a combination of poorly performing representative institutions, negative media coverage and the apathy of ordinary citizens (for a review see Corbett 2014; 2015). In making this claim, however, this literature focuses exclusively on the relationship between the people and their governments. Hibbing and Theiss-Morse (2002) coined 'stealth democracy' to capture how apathetic and disillusioned citizens in the United States were about government and their political leaders in particular. Stealth democrats want as little to do with policy and policy-making as possible, and only engage under sufferance. The alternate 'folk theory', Stoker and Hay (2012) claim, is a 'sunshine' view of contemporary democracy (see Neblo et al 2010) where citizens believe in democracy but dislike the way it is practiced by selfserving elites. As such, they are happy to engage with politics providing the policy process meets their ideal of a level playing field. The normative stance differs markedly between these two views - echoing older debates in political theory - and each is 
grounded in survey material from around the world. In both cases, however, the orthodox assumption is that a pluralist elite dominates policy-making and that a growing 'gap' between citizen expectations and their actions and conduct underpins rising disaffection.

In this article we come at this topic from a different angle by bringing the hitherto unrecorded views of policy elites, whose actions are often central to citizen disaffection, back in to discussions about anti-politics and disenchantment with democratic government. This move is significant because it allows us to explore the main alternate to the 'gap' explanation, the account of anti-politics as a perpetual 'trap' whereby we place competing and contradictory demands on our leaders that they cannot ever hope to meet (Hajer 2009; Kane and Patapan 2012, Medvic 2013). Echoing the old Weberian view of policy-making as a 'slow boring of hard boards' (Weber, 1978), the normative expectation that permeates the 'trap' account is that elites will be 'stoic' in their outlook towards the policy process.

The 'stoic democrat', in the 'trap account', is constructed as a hopeful and resilient figure whose perseverance keeps the wheels of democratic governance turning. Stoicism in the classical sense is associated with a virtuous detachment from emotion and objective concerns (Sharples 1996, 100-101), but the more prosaic use of the term used here also captures the jaded sense of frustration and fatalism that permeates the actions and reflections of policy actors. 'Stoic democrats' see politics and policy making as a grinding slog of incremental gain—one that is in many ways perverse and unfair—but they retain the vocational commitment to continue in full knowledge of the 'trap' they 
work within. Adopting an interpretive approach, which asks how the policy actors involved in policy engagement on the issue of obesity in Australia and Britain experience and perceive the process, we seek to better understand what being at the core of a complex, demanding issue like obesity entails.

Largely, we find that the theoretical and empirical representation aligns. Most policy makers are both cynical about the process and their role within it, while remaining deeply committed to the prospect of long-term success. Thus, much of our analysis supports the emerging 'trap' account of anti-politics. However, some are also frustrated by the endless stoicism required of them by contemporary representative democracy; will this issue ever be resolved, they ask? I get the slog part, they reflect, but will I ever taste the rewards? Indeed, in part it is the grinding expectation that they will be stoic that they have become so cynical about.

So, we also reveal a group of policy actors who are not, like members of the lay public, disaffected with the way policy processes operate because they do not fathom them. Rather, they are disaffected because they understand all too well how the policy-making 'game' is played. Indeed, aside from oblique references in satirical shows like The Hollowmen, these views are often not obviously apparent front stage - many take great care to express a positive view in public forums and hearings - but backstage, once the cameras and microphones are off, their cynicism is palpable; they complain about the motivations of the other actors involved, the openness of the decision-making process, and the prospects of their participation making any substantive difference. As a result, 
some are challenging the legitimacy of formal policy processes, subverting their norms, or ignoring them altogether, all in search of more direct impact; they want to spring the 'trap'. This latter reflection, we argue, points us back in the direction of the 'gap' account as it highlights changing expectations rather than fixed paradoxes. We conclude, therefore, that both the 'gap' and 'trap' are important for ongoing conceptual and empirical work on the anti-politics phenomenon. However, to fully appreciate this, and thus link both sides of the debate, we need to pay closer attention to both elite and citizen views about the policy process.

Let us briefly insert two caveats before we begin. First, we acknowledge that the world of policy elites we depict is one commonly portrayed as being dominated by policy networks not hierarchies. More in-depth longitudinal analysis is required to parse out whether this change has caused the rise in elite cynicism but for now our more modest and fundamental aim is to illustrate that it exists and should be taken seriously. Second, to be clear, the conclusion we draw from this account is not that a tendency to spring the 'trap' is somehow dangerous or undesirable in democratic terms; agitation and protest have long been a force of dynamism in democratic systems. For the more competitive account of democratic governance, like that of E. E. Schattschneider (1960), it is precisely this sort of conflict which galvanises public interest and challenges elite domination. ${ }^{1}$ Indeed, outbreaks of such conflict can be seen as key drivers of the very practices and institutions of deliberative or collaborative governance whose legitimacy, at least in our extreme case, is beginning to come into question (see Fung 2005). Cognizant of this perspective, we conclude by suggesting that a better understanding of elite 
cynicism amid the governance ‘trap’ and its corrosive effects on the sort of stoicism assumed of elite actors can, when set against the prevailing expectations 'gap', help in shaping and driving further renewal.

\section{THE GOVERNANCE 'TRAP’ AND 'STOIC DEMOCRATS’}

In contrast to the 'gap' view of prevalent but soluble democratic imperfection, the 'trap' view conceptualizes the problem of anti-politics and public disaffection as a fundamental paradox of democracy. The bulk of this literature has focused on the role of politicians, and the ways they are wedged between trying to fulfill the contradictory demands of democratic publics (see especially Hajer 2009; Medvic 2013 and Kane and Patapan 2012). These paradoxes come in several forms (see especially Medvic 2013): we want our policy makers to follow public opinion but also lead by direction (the leaderfollower-trap), hold firm to principles and beliefs while compromising to solve problems (the principled-and-pragmatic-trap), and be like us, so they can understand us, but also better than us, so they can rule over us legitimately (the ordinary-and-exceptional trap). Rather than holding ‘stealth’ or ‘sunshine’ views about democracy, the ‘trap’ view emphasizes that in the face of these contradictory demands policy-making requires a level of 'stoicism' from its practitioners, which here we extend from politicians to the broader cast of elites involved in networked governance.

Seen in this light, the actors in our analysis are 'trapped' in the sort of cynical cycle that Cappella and Jamieson (1997: 19) so succinctly described. Much like disaffected citizens, they see the system as corrupt and the players as self-interested; strategically perpetuating 
a 'winner takes all' game to their advantage. Where they differ, however, is their beliefs are based on intimate 'insider' knowledge of exactly how that game is played. The front stage expression of this sentiment is the satirical representation captured by The Hollowmen. The backstage view is more radical, with some of these actors actively seeking to subvert the established rituals of engagement and conciliation in search of greater impact; they want to break and remold the rules.

While the 'gap’ view of anti-politics rests on a version of David Easton's (1965, 212, 216) argument that political systems in which the governed do not support or have confidence in those who occupy authority roles tend not to survive, the 'trap' account better recalls the assumptions underpinning Bernard Crick’s (2000) famous defence of politics and his caution against elites losing faith in the system of compromise and conciliation that democracy seeks to uphold. Our use of the term 'stoic democrats', in this sense, echoes Crick's (1963) view of democracy as underpinned by a sort of 'gentlemen's agreement' to play by the rules and the older Weberian view, outlined above, of policymaking as a 'slow boring of hard boards'. In this conception, politics and policy making seeks practitioners with the vocational commitment to persist in spite of the 'trap'.

Though such a conception can be traced back to an earlier hierarchical model of policymaking, it is a tradition that, as our material reveals, carries over to a contemporary era characterized by networked interdependence. The new practices of deliberative governance that surround complex and contested issues like obesity are, in this sense, a response to the declining legitimacy of earlier practices. They represent concessions that 
appease disenchanted elites and encourage them to remain stoically committed to the process (see Hajer and Wagenaar 2003). Though the success of these new practices has been much heralded (Ansell and Gash 2008), they continue to demand resilience, patience and tempered expectations from the actors involved—demands that are especially acute in relation to 'wicked' problems like obesity, and which, we shall see, can breed considerable cynicism among the actors involved. Many remain stoic, but vocal minorities are growing more restless about the endless stoicism required of them. So, our cases illustrates both the strengths of the 'trap' account - it can help us understand the perpetual tensions that lie at the heart of democratic government - and the limitations - it tells us very little about what has changed. Before launching into this account, however, it is important to outline the approach we took to uncovering and analysing these elite perspectives on policy making.

\section{APPROACH}

The analysis that follows is based on an in-depth, qualitative case study of deliberation on obesity across a range of democratic sites in Australia and Britain. ${ }^{2}$ Drawing on over 1000 documents, 25 hours of video footage, and 36 semi-structured interviews (see Table 1 for a breakdown), we set about determining how actors engaged in this policymaking network experienced and perceived the process and their role in it. The approach was, in this sense, interpretive. Though typically associated with an effort to bring to light the views and experiences of the marginalized (see Schwartz-Shea 2006), interpretive research is equally valuable as an approach for 'studying up', shedding new light on the beliefs and practices of elites, too (see Rhodes 2011). The theme of cynicism, and its 
links to anti-politics, was something that emerged inductively, and which interview participants were particularly keen to reflect and dwell on. Accordingly, the analysis is presented primarily in their own words (in line with Bevir and Rhodes 2006; Rhodes 2011).

Table 1: The deliberative systems on obesity

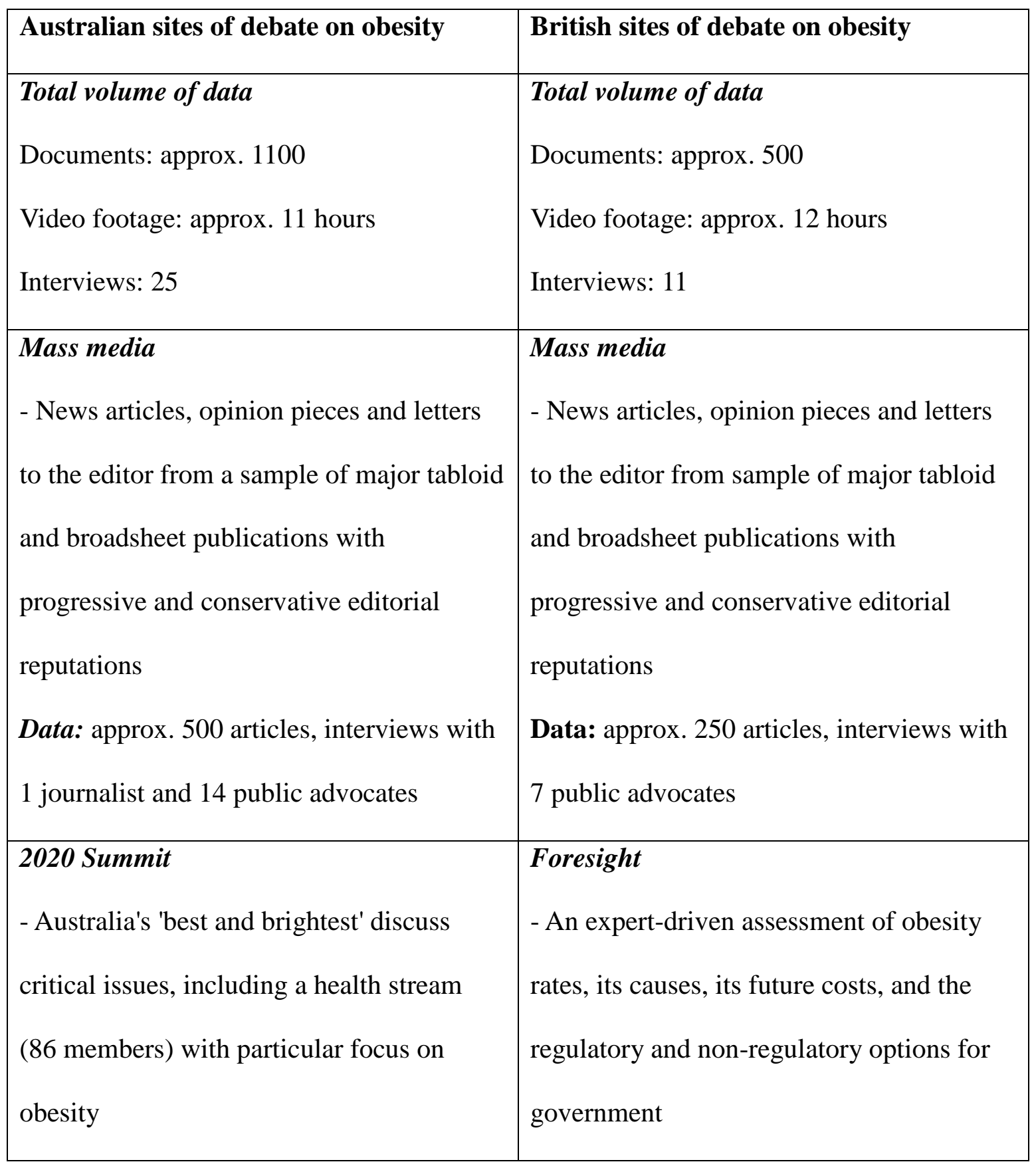




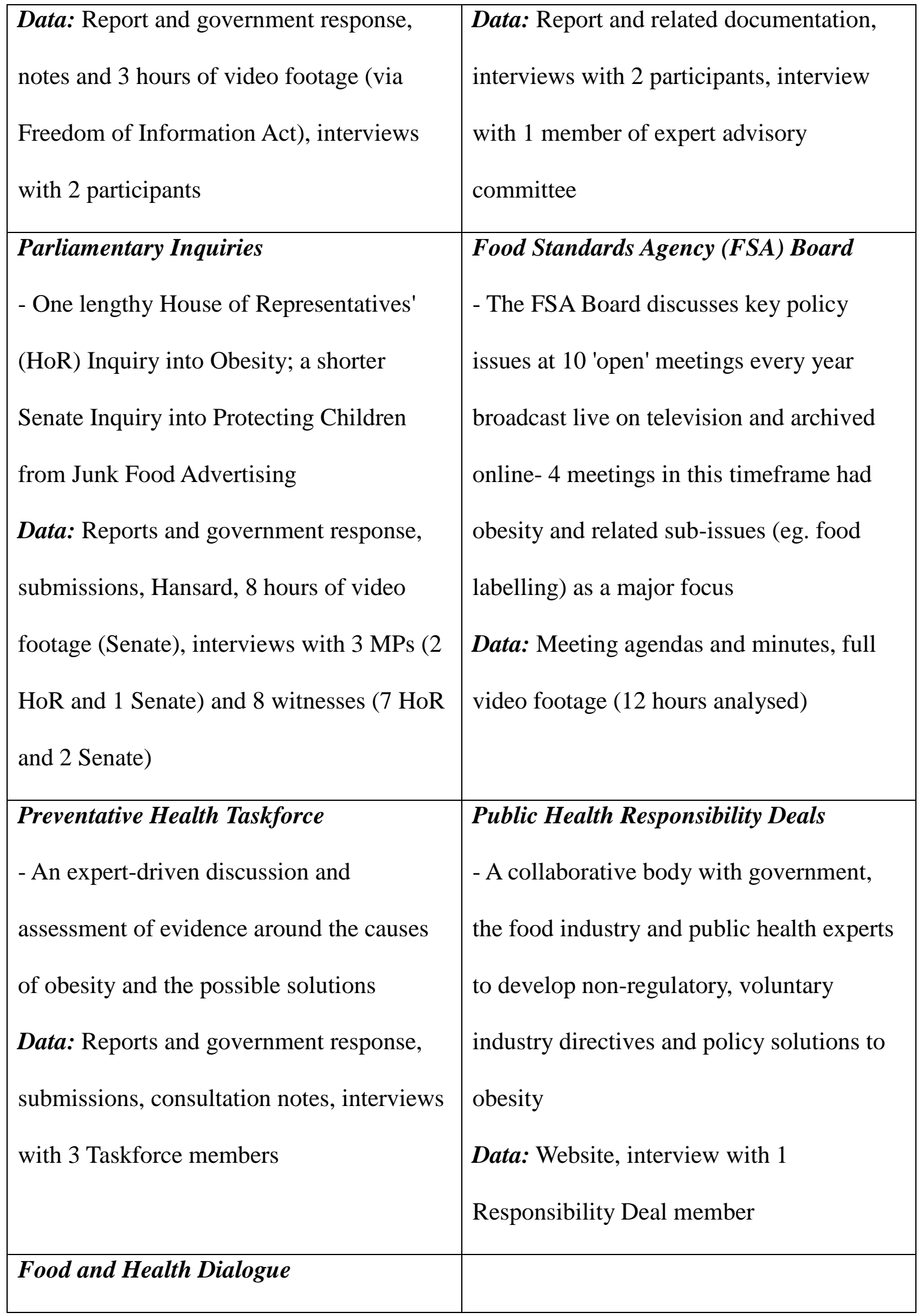




\begin{tabular}{|l|l|}
\hline - A collaborative body of government, food & \\
industry and public health representatives & \\
working mainly on food reformulation & \\
targets & \\
Data: Communiques, website, interviews & \\
with 3 Dialogue members & \\
\hline
\end{tabular}

Idiosyncrasy has long been a criticism of single case, qualitative research and we acknowledge that the case of obesity is not a typical one through which we hope to unveil covering laws. In one sense, obesity is a newly emerged issue, and as such many of the actors intimately involved in the relevant policy community are relative newcomers to the policy realm. As our analysis will show, some express disaffection as a sort of 'culture shock', having confronted the seemingly perverse aspects of policy work that more experienced actors may take for granted. This is especially so since obesity has emerged as a tangible threat to powerful and long-entrenched interests in the food industry, whose relationships and contributions cut across many policy sectors. There is inevitably a significant discrepancy between the hopes and demands of newcomers primarily from the health sector and the actions which government is willing to pursue, recalling the expectations 'gap' in the dominant view of anti-politics. In another sense, obesity is also an archetypal 'wicked problem' (Rittel and Webber 1973). Like climate change, social injustice and the ageing population, it is a complex, multifaceted issue beset by clashing interests and philosophies. It is, perhaps, insoluble — and for that reason has all the 
characteristics we might associate with a ‘trap'. Even though a networked, dialogic approach is typically held up as best practice for handling such problems (see APSC 2007; Ferlie et al. 2011), we might nevertheless expect that these characteristics inevitably induce fatigue and frustration on the part of those most centrally involved in working towards a resolution.

Nevertheless, we maintain that these atypical features also make obesity an enlightening case through which to explore anti-political sentiment. Indeed, it is its 'extreme' nature, and these clear links with competing explanations of anti-politics, that make it so valuable (see Flyvbjerg 2006 for more on the logic of using 'extreme’ cases). The experiences and perceptions that we discover in relation to obesity represent acute manifestations of a broader set of phenomena, apparent in relation to other newly emerged and wicked problems and perhaps beyond. We will return to this point in our conclusion. For now, however, we will simply suggest that the sentiment recorded here has some resonance with policy work more broadly. This is, after all, what gave The Hollowmen such appeal among policy ‘insiders’ (see Staley 2008).

\section{THE ANALYSIS: UNPACKING ELITE CYNICISM}

Obviously not all policy elites think the same about the issue of obesity-indeed, there are vocal and bitter conflicts across, and within, many of the classes of actor invoked in our account, including medical professionals, NGO representatives, public health academics, food industry representatives and beyond. Some see obesity as an individual weakness, others as a societal failing; some see the cause of growing rates of obesity as 
genetic, others as socio-economic; some demand greater spending on treatment for obese patients, others want to see a focus on regulating the food industry (see Boswell 2014). However, despite the diversity in the views that actors hold, all make sacrifices and share a sense of frustration that their hard work is unrewarded.

The sense of endless thwarted endeavor is best captured in this British public health expert's far-reaching critique of consecutive governments' policies on obesity:

Issues like obesity and overweight and the concomitant diseases that come with them like the rise in NCDs [non-communicable diseases] just are not addressed by the 'sickness service' [the NHS]. They're about how we live. They're about the food supply chain. They're about people getting into their cars to go to a supermarket instead of walking ... It's also built into the ubiquity and the avalanche of calories that hit us: the shift in sizes; the shift from water to soft drinks; the sweetening of diets. That complexity was completely lost on the Blair government. .... [Now under the Coalition government] we can have confectioners who sell chocolate saying they're signed up to the corporate Responsibility Deal and say 'we're actively participating in Change4Life.' I mean this is pathetic.

But crucially, at the end of this outpouring of frustration, he immediately added the rider:

But I'm not going to poo-poo it. I'm not a sceptic. I've worked on food policy for nearly 40 years. I've seen the difficulty in getting issues on the agenda. But also it does make a difference. Obesity is an issue that's discussed. (interview with British public health expert, March 2012). 
Like this actor, most remain stoic. While publicly committed to the process, they are despondent behind the scenes. Typically, their frustration is expressed in three forms: 1) The process is inert; 2) The process is compromised; 3) This process is 'a show'. We unpack each in turn before discussing the implications of these views, and the manner in which they are testing the limits of the 'stoic democrats' at the centre of policymaking, for how we think about democratic legitimation and anti-politics.

\section{The process is inert}

Much of the most important work in policy studies has been devoted to outlining and explaining the policy process as a painstakingly slow one of infrequent or marginal gains. The combination of institutional inertia, political reticence and powerful vested interests can make policymaking very much 'the slow boring of hard boards' Weber described. This characteristic is particularly acute in relation to an issue like obesity which is newly developed, complex and multifaceted in nature, and potentially threatening to established and powerful corporate interests. Indeed, actors commonly draw parallels to climate change as a similarly emergent 'wicked' policy problem that government, divided institutionally and historically into discrete silos, focused on short-term objectives, and cowed by the possibility of an industry-led backlash, is completely ill-equipped to deal with (see Swinburn et al. 2011).

Elite cynicism in part stems from frustration that policy processes can ever work fast enough to keep up with such an urgent problem. An Australian NGO representative explained it this way: 
The analogy I often use is the urban myth of the boiling frog ...That government's respond quite well to the crisis situation, so when you have a salmonella poisoning in food and lots of people get sick and so forth, we can respond very quickly and very effectively, I think. Where we're actually poor at responding is when it comes on us slowly... obesity is actually a very, very good example of something creeping up on us (interview with Australian NGO representative, April 2011).

A bureaucrat concurred, only for her the key issue was complexity rather than urgencythe traditional silos of government are ill-suited to dealing with such a multifaceted issue: Nutrition is not rocket science; it's a whole lot harder. Because our relationship with food is so complex. There's cultural elements. There's safety elements. There's the sheer necessity of it-we all need it every day. There's cost elements. There's everything from the farm gate through to the most highly processed foods (interview with senior Australian bureaucrat, June 2011).

As such, in her view, policy progress was always likely to be labored and inadequate to tackle the scale of the problem:

I think we're really talking about a really long-term situation. It's going to be about incremental moves, and small increments at that.

And a British scientist, reflecting on both points, was even more defeatist in tone: 
If you really want to reduce obesity, probably have an oil crisis. I mean the scale of obesity as a problem is just astonishing, and not quite out of control but not far off (interview with British academic, March 2012).

For the most part, despite these privately expressed misgivings, actors across the policy network remain publicly hopeful about the prospects of suitably urgent, integrated policy action. British Department of Health official Will Cavendish, in his presentation of the department's new nutrition strategy at the open board meeting of the Food Standards Agency in July 2011, for instance, was immensely upbeat about the plan the government was putting in place to tackle obesity. Likewise, Australian National Heart Foundation Director, Lyn Roberts, in her testimony to a Parliamentary Inquiry, spoke of her admiration at the progress being made on integrated thinking on this complex issue.

Yet, interestingly, not all elite actors are so stoic in their public enthusiasm. Indeed, we find evidence that backstage frustration seeps into the front stage of policy discussion, too, particularly through the public advocacy of more radical NGO representatives, scientific experts and medical professionals. Driven largely by dismay that the agenda remains dominated by cosmetic or 'placebo' policies ${ }^{3}$ as policymakers balk at options which offend the food industry (or so it is perceived), some of these actors are beginning to feel that drastic, rather than slow and piecemeal, action will be needed before it is too late. For instance, Boyd Swinburn, then Australia’s most outspoken public health academic, explained in an animated appearance on the television debate show SBS Insight: 
We've had a national obesity taskforce that came to nothing. We've had reviews of junk food advertising on TV. That's been sitting in abeyance for two years. We've had all sorts of things put on the back burner and I think it is time the government stepped up with leadership.

In this sense, the limits to stoicism are being tested—a point we will revisit regularly emphasise in our concluding discussion.

\section{The process is compromised}

Hand-in-hand with these perceived structural forces of inertia, the actors in our analysis speak of their inability to exercise influence by following the norms of engagement in policy work and deliberation on obesity. Such lack of capacity stems not just from the delayed, indirect influence of advocacy and public deliberation and convoluted, slow nature of policy work in any case, but from a sense that rival actors are actively blocking progress. The surface commitment to procedural fairness in practices of policy deliberation is, in these accounts, undermined by the lobbying, threats and grandstanding of key adversaries. Such perceptions of powerlessness, and attribution of influence to the other, resonate with older scholarship on politics and policymaking. Indeed, frustration and a perceived lack of influence in the contingent and time poor realm of decisionmaking is a recurrent theme in interpretive scholarship on politics and policy (Rhodes 2011), common apparently to elected and civil service officials, actors in civil society and corporate interests all alike. 
Most notably, for many of the scientists, NGO representatives, and professionals involved, the material resources that the food industry can bring to bear render this surface equality of process invalid. A British clinician surmised dramatically:

I've said to many people it's a bit like David and Goliath when the medical profession stands up against the food industry, when 15\% of the population are employed in some form or another by the food industry (interview with British clinician, June 2012).

Some of these actors see the pharmaceutical industry as a bigger obstacle than the food industry. Others even see fellow 'public health experts' as a key problem, believing that certain prominent individuals exercise inappropriate influence over obesity policy deliberation, while potentially more worthy ‘experts’ are left out. One scientist in Australia, for instance, remained bitter about her exclusion from a special taskforce: I found it pretty strange that I wasn't invited considering I've got the best dataset in Australia [on a particular sub-issue associated with obesity]... I was fairly flabbergasted that I wasn't invited. I'm an expert about [this sub-issue] and I didn't get invited to the Preventative Health Task Force.

Indeed, many non-experts are wary about the influence and accountability of key scientists, NGO representatives and medical professionals. One policymaker, for instance, referred repeatedly to these actors as 'zealots' and warned about the dangers of them 'hijacking' the policy process. Food industry representatives, unsurprisingly, also expressed resentment at the capacity of expert actors like scientists, NGO representatives 
and medical professionals to set the institutional agenda and marginalize the industry voice.

Again, though more typically kept private, we also see these predominantly backstage frustrations leak out into some of the front stage discussion of obesity in both Britain and Australia, as actors become less willing to carry on stoically in the face of perceived injustice. Perhaps the most prominent example has been in response to the Coalition government’s instigation of a series of so-called 'Responsibility Deals' in Britain, involving voluntary collaboration with the food industry on issues like health promotion and the reduction of sugar, salt and fat in processed foods. This manoeuvre met with damning accounts of 'Coca Cola and McDonalds' being allowed to write Britain's health policy—criticism subsequently piqued as moderate NGOs and professional groups, initially involved in the Responsibility Deals, have withdrawn their participation and publicly questioned their fairness and openness. On doing so recently, for instance, the Faculty of Public Health (or FPH) released a statement:

There is no evidence that the 'softly softly' approach of engaging with industry rather than using legislation to improve people's health has been more effective or quicker. That's why FPH has decided it can no longer be part of the Responsibility Deals, because we believe there are more effective ways for our expert members to influence policy and improve health (FPH chair John Ashton in Sparrow 2013). 
What particularly interests us, though, is that such cynicism, whether held privately or expressed publicly, is largely restricted to perceptions of their efficacy within the established avenues and norms of engagement. Those unwilling to continue acting as 'stoic democrats' are much more optimistic about their capacity to exercise influence by moving beyond this status quo-a point we return to later.

\section{The process is 'a show'}

Finally, many actors, at least in private, speak about the advocacy surrounding obesity policy work as 'a game'. The perception, satirized by The Hollowmen but again common to actors of all types, is that the formal processes of deliberation on obesity are 'for show', divorced from the 'real' processes of decision-making and implementation. For many scientists, NGO representatives, and medical professionals, the industry commitment to being 'part of the solution' on obesity and insistence on 'being at the table' represents little more than a public relations exercise:

The track record of working with corporate interests in an attempt to produce soft measures has a bigger track record of being good for corporate responsibility rather than good for public health (interview with British academic, March 2012).

Industry representatives are equally cynical about the authenticity of their adversaries in the 'public health lobby'. One industry representative reflected on a rare occasion where he actually felt that policy makers and rival actors were open-minded in their engagement with him: 
A time when we have experienced healthy debate is when we have reached out in these types of outreach stakeholder engagement programs, and there are no cameras there, no one is looking to get their sound bite on the 6 o'clock news, no one's looking to advance in their various industry associations by the boss seeing that they've taken a swipe at the horrible beverage manufacturers (interview with Australian industry representative, June 2011).

Engaging still provides a sense of purpose for some actors, especially those new or marginal to the network. The archetypal 'stoic' British health expert quoted at length at the start of our analysis, for instance, spoke of his gratitude at having been invited into the inner circle of an inquiry into obesity. Likewise, the Australian referenced earlier who felt frustrated and upset that she was not involved in important expert deliberations of a prominent taskforce in Australia, reflected on her deep satisfaction when she was asked to provide testimony at a parliamentary inquiry:

Professionally, it was one of the best days of my life. It was like: 'Now I'm saying this. Now I'm showing you this graph. Now I'm showing you this data. Here's this evidence—good, hard, cold evidence'... I really appreciated that opportunity (interview with Australian academic, July 2011).

Yet alongside some of the actors who participated regularly in such practices, or more pertinently who had significant influence behind the scenes anyway, the few statements we came across in this vein appear naïve, indicative of an uncertain place in the network. As this suggests, the cynicism on the three fronts we identify, most especially the use of 
metaphors like 'show' or 'game', is reflective of an insider status among the actors

involved. Cynicism in this sense is an identifier of being privy to the action backstage just as much as that occurs in the front stage of engagement and deliberation. Even more so than that, its manifestation on the front stage is also revealing of one's place in the network. For most actors, cynicism imbues and reinforces a sense of stoicism. But it can actually embolden those at the hub of the network who have greater leverage with which to influence the rules of the game. Deepening cynicism can encourage them to throw off the demands of stoicism and challenge the formal processes in which their involvement is deemed vital for democratic legitimacy.

\section{THE LIMITS TO STOICISM: CHALLENGING DEMOCRATIC GOVERNANCE}

Indeed, some of these actors assert much greater enthusiasm for realizing influence via more subversive or direct avenues. One such avenue involves duplicitous engagement in practices of democratic governance. That is, some actors are continuing to be seen to 'play along', but are undermining the processes they are involved in to further their cause, or else using their participation to gather information so as to exercise influence outside that particular setting. One Australian food industry representative, for instance, shared an anecdote about her response to a dysfunctional committee meeting with policy makers and NGO representatives on food reformulation:

There was a moment when it looked like it was going to fall apart so I put out a somewhat tongue-in-cheek press release about the government banning Vegemite. Because, you know, fundamentally if the government legislated to reduce salt they'd take Vegemite off the shelf... It's really hard to reduce salt in Vegemite 
without buggering up the taste. And Australians don't like buggering up the taste of Vegemite... That was funny. We had the Prime Minister out within 20 minutes talking about what a great product Vegemite was. (interview with Australian food industry representative, May 2011).

Not all interview participants were so frank in their on-the-record remarks about this phenomenon. Nevertheless, many indicated that the twin desire to 'learn from the enemy' and gather information about the direction of official policy represented some of the primary motivations for being engaged in otherwise pointless or turgid meetings.

We also find evidence of actors not just duplicitously 'playing along', but opting not to engage in formal deliberation on obesity at all. This shift is best typified by the comments of one prominent advocate for medical professionals in Australia, whose organization enjoys a very sure footing in policy networks surrounding all key health issues. When asked to explain his organization's lack of engagement, he and his colleague (also present at the interview) began joking about the 'tunnel' underneath the hill in which Australia's Parliament is situated, where reports and documents are literally buried:

It doesn't matter what stuff gets churned up through the Taskforce, the 2020 Summit, when it's all in the tunnel the government can decide what to do with it.... And as far as Parliamentary inquiries are concerned, having worked in Parliament as a staffer on Parliamentary committees and also having worked independently in Parliament, probably the last place you'd want to go to try and change policy is to put in a 
submission to a Parliamentary inquiry (interview with Australian medical professional representative, August 2011).

Formal engagement was, quite simply, not worth the time or effort.

\section{CONCLUSION}

The cynicism we uncover among policy actors is, of course, broadly applicable to many professions. All jobs breed their share of discontents, and we might expect that the elites involved in policy deliberation on obesity would be no different. From this perspective, the significance of our case is that it punctures the popular image of elite collusion, further illuminating the 'trap' account of anti-politics. It brings to the fore the human side of policy elites and places the 'stoic democrat' alongside the 'stealth' and 'sunshine' portrayals that dominate the existing literature.

Having made that point, however, what this case also reveals is that although most actors are cynical about the 'game', small but significant numbers are no longer willing to stoically carry on playing it; the move to undermine, subvert or opt out of the practices and institutions of deliberative governance represents the most intriguing finding from this study. What should we do when some actors will not remain stoic? Here is where fruitful links to the 'gap' account of anti-politics come back in.

First, though, we must accept that this development may be related to the extreme nature of our case. There is reason to believe that the same discontent so viscerally on display here may apply elsewhere. Cynicism of this sort is likely to be common among 
environmental campaigners on climate change, for example, where we already see some actors rejecting the democratic process in favour of eco-authoritarianism (see Shearman and Smith 2007). Accordingly, our findings should have resonance across a number of key areas of government attention; in such circumstances, there clearly are limits to the stoicism of the actors involved, and this presents a significant challenge to new processes of deliberative or collaborative governance like those in our analysis. But, we need further research to parse this out.

Having issued that caveat, one normative response to this challenge is to reassert stoicism as a standard for those tasked with governing democratic polities. In this view, policy actors have an exaggerated view of their participation, and the impact and timescale in which change might be achieved. So, our case could be read to support Crick's view that it is crucial for elites to retain faith in the system of compromise and conciliation that democracy seeks to uphold. Logically, if we can temper the expectations of policy elites, then they will be less inclined to try and spring the 'trap'.

The alternative normative response, associated with Schattschneider's more competitive account, is to celebrate the challenge presented by actors seeking to contest the current modes of democratic governance. In this view, the growing 'gap' presents an opportunity to reengage marginalized publics and remake the system. In this view, which typically sees itself as responsive to and representative of citizen disenchantment, subverting, undermining or ignoring formal mechanisms is crucial to the dynamic process of democratic legitimation. This is, after all, where many of the institutions and practices in 
our account sprung from in the first place. ${ }^{4}$ As such, the unwillingness of a critical mass of actors to remain stoic may generate further change. If key actors refuse to take part or work to undermine processes of deliberative governance, and their primary function of legitimating policymaking on complex and contested issues cannot be fulfilled, then they would have no point and we would need new means of legitimizing policy decisions. ${ }^{5}$

The most fruitful response, we suggest, will involve a fusion of these two perspectives. The 'gap' challenge can help to shape and drive reform, but the institutions and practices it produces will, in all likelihood, create new 'traps' of their own. Much as our account unveils about actors’ experiences and perceptions of recently emerged forms of deliberative governance, any evolution will involve reinterpreting and reasserting the stoicism required of the actors who take part. Seen in this light, new practices prompted by the unwillingness of actors to maintain the status quo will not solve complex governance problems like obesity once-and-for-all. They will simply strive to better produce contingent agreement around the process and confer greater legitimacy on outcomes, at least for a time.

Sketching out what any such practices or institutions might look like is beyond our scope. What we can do, though, is highlight the importance of considering elite views in this enterprise. So far the loudest calls for democratic renewal have stemmed from the 'gap' account of anti-politics, with its focus on citizen perspectives. The standard answer is that if people were allowed greater involvement (Stoker 2006; Hay 2007), or were at least helped to understand the promises and limitations of democratic politics better (Flinders 
2012), then they would be less disaffected with its outcomes. But our findings shed considerable doubt on these assertions. Unlike citizens who lack 'insider' knowledge of how politics is practiced and access to formal channels of influence, for the policy actors canvassed here it is their all-too-intimate understanding of 'the game', and of the endless stoicism required of them in playing it, that they are so cynical about. The lesson is that disillusionment with democratic governance is common to both elite and citizen actors, and that this should be reflected in future work not just on anti-politics as a phenomenon, but on associated efforts to renew democratic practices. Only by appreciating both views and the links between them—-for which this article provides an important initial insight— can we gain a more holistic understanding of contemporary anti-political trends, and the implications for the future of democratic government.

\section{BIOGRAPHICAL INFORMATION}

John Boswell is a Lecturer in Politics at the University of Southampton and an Honorary

Fellow at the ANZSOG Institute for Governance and Policy Analysis, University of Canberra

Jack Corbett is a Research Fellow at the Centre for Governance and Policy, Griffith University

\section{ADDRESS FOR CORRESPONDENCE}

John Boswell, Highfield Campus, University of Southampton, SO171BJ:

j.c.boswell@soton.ac.uk 


\section{ACKNOWLEDGMENTS}

We would like to thank Dennis Grube and Rod Rhodes for comments on earlier drafts of this manuscript.

\section{Notes}

${ }^{1}$ Though we revisit Schattschneider's perspective briefly in the conclusion, we cannot hope to do it justice. Instead, we direct readers to Mair (1997), which provides an excellent starting point for understanding his enduring appeal.

${ }^{2}$ Our analysis of Australia and Britain was initially intended to be comparative in nature. In practice, however, the differences between the two were minimal and the commonalities overwhelming, and so functionally they operate as a single case. This evolution aligns with best practice in interpretive research, whereby preconceived analytical categories often dissolve upon immersion in the empirical data (Flyvbjerg 2006).

3 'Placebo policy' is how Gustafsson and Richardson (1979) describe a policy favored for its capacity to manage the agenda rather than solve the problem. The classic example in obesity is social marketing, which attracts much publicity despite being known to have no effect on population health.

${ }^{4}$ See, for example, Hajer (2009) on the FSA in Britain or Davis (2008) on the 2020 Summit in Australia.

${ }^{5}$ Something like this has occurred with the public rejection of the 'Responsibility Deal' on alcohol control, for instance (Hawkins et al. 2012). 


\section{REFERENCES}

1. Ansell, C. and A. Gash (2008). 'Collaborative governance in theory and practice', Journal of Public Administration in Theory and Practice, 18(4): 543-571.

2. APSC (Australian Public Service Commission) (2007). Tackling Wicked Problems: a public policy perspective. Australian Government, Canberra.

3. Bevir, M. and R. A. W. Rhodes (2006). Governance Stories. London and New York, Routledge.

4. Boswell, J. (2014). “Hoisted with our own petard': evidence and democratic deliberation on obesity’. Policy Sciences, 47(4): 345-365.

5. Capella, J.N. and K. H. Jamieson (1997) Spiral of cynicism: The press and the public good. Oxford and New York: Oxford University Press.

6. Corbett, J. (2014). ‘But why do we need politicians? A critical review’. Policy Studies, 35(5): 498-512

7. Corbett, J. (2015). "Diagnosing the Problem of Anti-Politicians: A Review and an Agenda.” Political Studies Review.

8. Crick, B. (2000) In Defence of Politics. Great Britain, Continuum.

9. Davis, G (2008), 'One big conversation: the Australia 2020 Summit', Australian Journal of Public Administration, 67(4): 379-389.

10. Easton, D. (1965). A Framework for Political Analysis. Englewood Cliffs, NJ: Prentice-Hall.

11. Fawcett, P. and Marsh, D. (2014), 'Depoliticization, Governance and Political Participation’, Policy \& Politics, 42(2): 171-188. 
12. Ferlie, E., Fitzgerald, L., McGivern, G., Dopson, S. and Bennett, C. (2011). 'Public policy networks and 'wicked problems': a nascent solution?' Public Administration, 89(2): 307-324.

13. Flinders, M. (2012). Defending Politics: Why Democracy Matters in the Twenty-First Century. Oxford and New York: Oxford University Press.

14. Flyvbjerg, B. 2006, 'Five misunderstandings about case-study research’, Qualitative Inquiry, 12(2): 219-245.

15. Fung A. (2005), 'Deliberation before the revolution: towards an ethics of deliberative democracy in an unjust world', Political Theory, 33(2): 397-419.

16. Gustafsson, G. and Richardson, J.J. (1979), 'Concepts of rationality and the policy process’, European Journal of Political Research, 7(4): 415-436.

17. Hajer, M.A. and Waagenar, H (eds.) (2003), Deliberative policy analysis:

understanding governance in the network society, Cambridge University Press, Cambridge, UK.

18. Hajer, M. (2009). Authoritative Governance: Policymaking in the age of mediatization. Oxford, Oxford University Press.

19. Hawkins, B. et al. (2012), 'Alcohol industry influence on UK alcohol policy: a new research agenda for public health’, Critical Public Health, 22(3): 297-305.

20. Hay, C. (2007). Why We Hate Politics. Cambridge, Polity Press.

21. Hay, C. and G. Stoker (2009). "Revitalising Politics: Have We lost the Plot?" Representation 45(3): 225-236.

22. Hibbing, J. R. and E. Theiss-Morse (2002). Stealth democracy: Americans' beliefs about how government should work, Cambridge University Press. 
23. Kane, J. and H. Patapan (2012). The Democratic Leader: How Democracy Defines, Empowers, \& Limits its Leaders. Oxford, Oxford University Press.

24. Mair, P. (1997) 'E. E. Schattschneider's The Semisovereign People’, Political Studies, 45(5), 947-954.

25. Neblo, M. et al. (2010). 'Who wants to deliberate - and why?', American Political Science Review 104(3): 566-583.

26. Norris, P. (2011). Democratic Deficit: Critical Citizens Revisited, Cambridge University Press.

27. Rhodes, R. A. W. (2011), Everyday Life in British Government, Oxford University Press, Oxford and New York.

28. Rittel, H. and M. Webber (1973), 'Dilemmas in a general theory of planning', Policy Sciences, 4: 155-169.

29. Schattschneider, E. E. (1960). The Semisovereign People: A Realist's View of Democracy in America. Holt, Rinehart and Winston.

30. Schwartz-Shea, P. (2006). 'Judging quality: evaluative criteria and epistemic communities', in Yanow, D. and Schwartz-Shea (eds.) Interpretation and Method: Empirical research methods and the interpretive turn. New York, M. E. Sharpe. 31. Sharples, R. W. (1996). Stoics, Epicureans and Sceptics: An introduction to Hellenistic philosophy. London, Routledge.

32. Shearman, D. J. C. and Smith, J. W. (2007). The Climate Change Challenge and the Failure of Democracy. Westport, Conn.: Praeger Publishers.

33. Staley, L. (2008). 'The Hollowmen and the sport of satire', Institute for Public Affairs Review, 60(4): 16-18. 
34. Stoker, G. (2006). Why politics matters: making democracy work. New York, Palgrave Macmillan.

35. Stoker, G. and Hay, C. (2012). 'Comparing folk theories of democratic politics: stealth and sunshine', Political Studies Association Conference, Belfast, April 3-5.

36. Swinburn et al. (2011). 'The global obesity pandemic: shaped by global drivers and local environments', The Lancet, 378: 804-814.

37. Weber, M. (1978). 'Politics as a Vocation'. In W. G. Runciman (Ed.), Max Weber: Selections in Translation, Cambridge, Cambridge University Press.

38. Wood, M., and M. Flinders (2014). 'Rethinking depoliticisation: Beyond the governmental', Policy \& Politics 42(2): 151-170.

Word count: 8000 (precisely!) 